\title{
NEEDS ANALYSIS OF ENGLISH LITERATURE STUDENTS IN ENGLISH ORAL COMMUNICATION
}

\author{
AnggaMaulana \& Fegy Lestari \\ anggamaulana1985@unpas.ac.id \& fegylestari@gmail.com
}

UNIVERSITAS PASUNDAN

\begin{abstract}
The purpose of this study is to identify factual information about the needs of students of English Literature in the activities and supporting factors of oral communication by using English, whether linguistic and nonlinguistic, and analyzing the difficulties of the situation of oral communication of English Literature students using English. This research uses descriptive method. Data collection is done through two stages: the questionnaire and the interview, followed by the review of someliteratures. The results of this study indicate that in general the students of English Literature feel that participating in a formal discussion is more important than the informal. While in terms of ability in the oral communication activity, generally students mastered informal communication activities. In terms of linguistic factors, the choice of vocabularies, and good and correct sentences are considered very important, although they only feel quite capable in it. It is also found that talking with self-confidence, having proper English pronunciation and mastering the topic of conversation become the important non-linguistic factors. The same thing does not happen on loudness and facial mimic. In general, students feel it is not important enough to master. Regarding situations that facilitate students in oral communication in English, they generally feel that well preparation, self-confidence, and mastery over vocabulary and what is being discussed becomes an easier factor. Different things revealed by most students about the difficult vocabulary and the lack of preparation in oral communication. It is difficult. As for things that require improvement, students generally feel that the confidence and the amount of vocabulary that is mastered should be improved in order to improve the quality of oral communication in English.
\end{abstract}

Keywords: Needs Analysis, Student Needs, English Literature, Oral Communication

\section{A.INTRODUCTION}

English learning in higher education plays a role in preparing students to be able to capable in the world of work. It is important for students to have "soft skills" such as the ability to socialize, communicate and express themselves to their "hard skills" (New Straits Times, 2007).

Today, oral communication skills in English play an important role in the world of work. As a matter of fact, in a variety of job advertisements, the ability to communicate using good English is one of the requirements for applicants. This good communication ability, particularly oral, can be seen directly when the applicant enters the job interview stage. This is because technical qualifications tend to be more or less the same among applicants. Given the importance of oral communication skills in English is worthy for students and the world of work, thus, every student should be given the opportunity to develop this important skill.

In the teaching process, oral communication materials are expected to meet the students' need for English in accordance with the needs of students in the taught subjects. The needs in each of these majors are worth noting because English used in oral communication differs from context to context (Hutchinson and Waters, 1987).

Students' need for English in a particular field can be explored through needs analysis (Richard, 2001) used to develop the objectives and content of learning; also provides data to evaluate existing programs (Richard in Nunan, 1988).

This research focuses on identifying the needs of English Literature students in oral communication skills using English. As it is well known that effective language learning can be achieved when the students recognize their needs based on their own ability, potential, and preference in meeting the needs (Bada \& Okan , 2000). Related statements also came from Brindley (1989, as quoted in Bada \& Okan, 2000), that English language teaching materials and activities should embrace what students need and what teachers should be given. 
The activity of oral communication in this research is focused on various learning activities and supporting factors of oral communication in English. Syakuro (2014) mentions that the supporting factors in the activity of oral communication include linguistic and non-linguistic factors. Linguistic factors include the accuracy of speech; appropriate tone, joint or duration tone placement; choice of words; accuracy of sentence use and grammar; and accuracy of the target of the conversation. While, the factors of non-lingustics include a reasonable attitude, calm and not rigid; eye sight; willingness to respect others; proper gestures and expression; loudness of sound; smoothness; relevance, reasoning; and mastery of the topic.

The purpose of this research is to:

identify some factual information about the needs of the students of English Literature in the oral communication learning activities and the supportingfactors of oral communication, both linguistic and nonlinguistic factors in using English, analyze the difficulties of the situation of oral communication of students of English Literature using English.

\section{B.LITERATURE REVIEW \\ 1.Needs Analysis}

A number of literatures talks about needs analysis. One is from Brindley (1984 in Richards, 2001) who thinks that the term needs often refers to "desires, demands, hopes, motivations, deficiencies, constraints, and needs." More specifically, Richards (2001) states that the need for language needs is defined as the language competence that is necessary to survive in the English-speaking community.

One of the basic assumptions of the development of instructional design is the needs analysis of students to be the basis of all matters relating to English learning. Richards (2001) says that the procedures used to collect information about student needs are referred to as Needs Analysis.

In the study of needs analysis, one type is student's need analysis (learner analysis) (Nunan, 2001). Students' analysis is based on information about students. This information can be used by the teacher in making the learning design more appropriate to the student's needs.

In the learner's analysis, the type of information obtained may be objective information, such as the age and nationality of the learner. While subjective information, such as the learner's perceptions and priorities, includes information on why students want to learn English, what tasks they want to get in English classes, as well as student-preferred learning activities. This study focuses on the subjective information. It is about the attitude and the views of students in learning oral communication using English.

So it can also be said that subjective information reflects the priorities and perceptions of students about what to teach and how to be taught. According to Nunan (2001), the objective of subjective needs analysis is to involve students and teachers in taking and providing information so that ideas from teachers and students can be more accommodated. Furthermore, Hutchinson \& Water (1987) argues that student learning needs analysis is needed so that teachers can better understand students' interests and begin the process of instructional design with information obtained from students, so that students' needs for learning can be more fulfilled.

\section{Student Profile of English Literature}

In Indonesian Language Dictionary (KBBI), students are defined as people who study in Higher Education (www.kbbi.web.id). In more detail, the student is a registered person and is studying or educating in one of the forms of higher education, be it academy, polytechnic, high school, institute or university (Hartaji, 2012), both public and private (Siswoyo, 2007).

In the developmental stage of a human being, ahigh education student is categorized into the late adolescence to the early adulthood of 18 to 25 years and the task of development is the stabilization of the life stance (Joseph, 2000). The age of the student is a major factor in deciding how and what to teach. Harmer (2001) states that people of all ages have different needs, competencies, and cognitive skills. Therefore, students who are late adolescents and early adults have their own characteristics, which are different from those of other ages. This period is the time span to establish identity, self-esteem, and the establishment of life (Harmer, 2002; Joseph, 2000).

Based on their characteristics, students need to be given a chance in deciding what and how they learn the effectiveness of the learning process. It aims to minimize failures in building relationships between what they need and what teachers should teach students. This is supported by Bada \& Okan (2000) who states that 
effective language learning can only be achieved when teachers understand their students, whether potential, ability, and preference in meeting the needs.

\section{Oral Communication Learning in English}

Learning is a conscious process that studies and practices every aspect of language (Krashen, 1980 as cited in Harmer, 2007). Krashen also says that teachers are encouraged to provide appropriate language exposure. In the more complete discussion, Allwright (1979) states that the goal of English learning is to enable students to communicate in English, so the best way to communicate is learningto communicate. Therefore, an English teacher should give the students a chance to practice their English skills.

According to Harmer (2007), there are four skills in language learning: Listening, Speaking, Reading, and Writing. The four skills can be divided into two types: Receptive Skills and Productive Skills). Receptive skills are terms used for listening and reading skills, skills in which meaning is taken from discourse. While productive skills are skills in the field of oral and written, the skills in which the students must actually produce their own language. This research focuses on oral communication of students by using English.

Oral communicating can be interpreted as the ability to pronounce language sounds to express or convey thoughts, ideas or feelings verbally (Brown and Yule, 1983). They add that in ordinary life, oral communication is considered an important human social control tool because this is a form of human behavior that utilizes the physical, psychological, neurological, and linguistic factors thoroughly. These factors are an indicator of the success of communicating verbally. In other words, all of these factors should be considered when the teacher determines whether or not the student is able to communicate verbally. This is consistent with what was expressed by Madsen (1983) that oral communication requires the proper use of language at an ideal level. The same thing is proposed by Syakuro (2014) who concluded that oral communication is defined as a medium to synergize ideas or ideas that are developed and developed in accordance with the needs of the opposite of communication.

Types of spoken communication are divided based on various aspects. In this study, the types of oral communication to be examined are limited by the behavior and intent or purpose of oral communication. This is based on the consideration that the two foundations are possible within the context of learning oral communication in the college environment.

Behavioral communication is communication that can be influenced by our peripheral behavior or the position of someone that happens automatically. Behavioral communication can be differentiated into: formal, informal, and non-formal communication (Heriyaningsih, 2010; Robani, 2013). Formal communication is communication that the way communication is organized in its organizational structure. This communication is common in situations of seminars, conferences, meetings, etc. Informal communications are communications that are not officially approved. For example, rumors or daily conversation. This arises from the encouragement of satisfying human needs or resistance to monotonous influences, the fulfillment of the desire to influence the behavior of others, or the service of information sources that are not provided by the channels of formal communication. While, the non-formal communication is the communication that occurs between the communication that is formal and informal among which are interrelated with the implementation of the duties of organizations or companies with activities that are personal. Non-formal communication will not be discussed further because this study focuses only on formal and informal communication.

Every human activity always has a purpose. According to Tarigan (1983), the primary purpose of communicating verbally is to convey the mind effectively. Verbal communication activities also require things beyond language skills and knowledge that can support the effectiveness of communicating verbally. Syakuro (2014) mentions that the supporting factors of oral communication activities include linguistic and nonlingusitic factors. Linguistic factors include the accuracy of speech; appropriate tone, joint or duration tone placement; choice of words; accuracy of sentence use and grammar; and accuracy of the target of the conversation. While, the factors of non-linguistic include a reasonable attitude, calm and not rigid; eye sight; willingness to respect others; proper gestures and expression; loudness of sound; smoothness; relevance, reasoning; and mastery of the topic.

On the other hand, there are times when the communication process experiences obstacles that cause the message received by the opposite of communication is not the same as what is meant by the speaker. According to Rabani (2013), these obstacles can be physical disturbances, i.e. interference with physical transmission of signals or other messages (others' speak, whistling passing cars, computer humming, glasses); psychological, i.e. cognitive or mental interference (thoughts already present in students' heads, prejudices and biases on 
receiver sources, narrow minds); or semantics, i.e. speech and listener give different meanings or misinterpret meaning (people speak different languages, using jargon or overly complex terms that the audience does not understand).

It can be concluded that one important aspect in communicating is the oral aspect. With oral communication skills students are able to express ideas and feelings in the context and situation of communicating verbally. To improve the communication skills orally, the need for students' involvement in the learning process is crucial. One of which is analyzing the needs of students on learning oral communication.

\section{C.RESEARCH METHODOLOGY}

This research uses descriptive method. Descriptive method is the most common method used in research in the field of education (Burns, 2000). Data were collected through questionnaires, interviews, and literature review. The subjects of this study are students who are currently studying in English Literature Department from various universities in Bandung area, namely UIN Sunan Gunung Djati, Padjadjaran University, Pasundan University, Widyatama University, Kebangsaan University, Maranatha Christian University, and STBA YAPARI Bandung (http: //www.ban-pt-universitas.com, 2015).

In this study the expected data is descriptive and verbal data that answers the question of why and how a phenomenon occurs resulting in in-depth understanding resulting from this research (McMillan \& Schumacher, 2001: 400). The study also attempted to view or interpret phenomena in the viewpoint of the subject under study.

Data collection is done through two stages: the questionnaire and the interview, followed by the reviewof some theories. In this study the researcher collects the data by distributing questionnaires to collect primary data in closed question form (a question can only be answered among the available options) \& open (questions that give freedom to respondents to give answers).

The questionnaire consists of four parts. Part A is respondent data, Part B that is about oral communication, part $\mathrm{C}$ is about linguistic and non-linguistic factors, and part $\mathrm{D}$ is oral communication situation. As for interviews, the questions asked in interviews with students are more or less the same as that proposed in the questionnaire. The result of this interview is expected to dig deeper information related to reason or further information from what is asked in the questionnaire. This is done to increase the level of trustworthiness of qualitative research (Alwasilah, 2008 and Cohen, et al, 2006: 141).

In analyzing the data obtained, descriptive method is used then poured in tabulation of data and matrix. After that, a descriptive analysis is conducted to obtain an idea of the needs of students in oral communication using English.

\section{D.RESULTS AND DISCUSSION}

This chapter discusses about the results that are temporarily obtained, namely the results of questionnaires and student interviews.

\subsection{Questionnaire}

The questionnaire consists of four parts. Part A is Respondent Data, Part B that is about oral communication, part $\mathrm{C}$ that is about linguistic and non-linguistic factors, and part D is oral communication situation.

1.2 Interview

The question asked in the interview with the students is more or less the same as that of the questionnaire, which consists of four parts. Part A is Respondent Data, Part B that is about oral communication, part C that is about linguistic and non-linguistic factor, and part $\mathrm{D}$ is oral communication situation. The results of this interview are expected to explore deeper information related to the reasons or further information of what is asked in the questionnaire. This is done to increase the level of trustworthiness of qualitative research (Alwasilah, 2008 and Cohen, et al, 2006: 141).

From the spread of questionnaires and interviews conducted on the students of English Literature above, it is obtained some information related to the needs of students of English Literature on English communication. The information gathered is categorized according to the research objectives.

As mentioned in the previous chapter that this study aims to identify factual information about the needs of the students of English Literature in the activities and factors of oral communication in English, both linguistic and non-linguistic, and analyze the difficulties of the oral communication situation of English Literature students by using English. 
In general, students of English literature feel that participating in a formal discussion, such as communicating in seminars, conferences or class situations, is more important than informal activities. Being able to do a good presentation gets a very important response. While on the scale of ability in the oral communication activation, in general, students feel more capable and mastering informal communication activities.

Syakuro (2014) mentions that the supporting factors in the activity of oral communication include linguistic and non-linguistic factors. Linguistic factors include the accuracy of speech; appropriate tone, joint or duration tone placement; choice of words; accuracy of sentence use and grammar; and accuracy of the target of the conversation. In terms of linguistic factors, information is obtained that the choice of words and sentences are good and correct is considered very important for students in engaging in oral communication activities in English, although they just feel quite capable in that activities. This is consistent with what was expressed by Madsen (1983) that oral communication requires the proper use of language at an ideal level. Furthermore, according to Tarigan (1983), the primary purpose of communicating verbally is to convey the mind effectively. In other words, the students in this study said that the choice of words and the composition of good and correct sentences can communicate ideas effectively.

While, the factors of non-linguistics include a reasonable attitude, calm and not rigid; eye sight; willingness to respect others; proper gestures and expression; loudness of sound; smoothness; relevance, reasoning; and mastery of the topic (Syakuro, 2014). In this case, it is found that speaking with confidence, pronunciation with proper English pronunciation and mastering the topic of conversation become the non-linguistic factors that are considered very important. The same thing does not happen on loudness and facial expression when engaging in oral communication activity in English. In general, students feel that they are not important enough to master.

The reason for this behavior corresponds to a behavior-based communication term. This is communication that can be affected by our peripheral behavior or the position of someone who happens automatically (Heriyaningsih, 2010; Robani, 2013).

Regarding situations that facilitate students in oral communication in English, they generally feel that careful preparation, self-confidence, and mastery over the vocabulary and topics discussed becomes a factor that facilitates oral communication activity. Different things revealed by most students about the difficult vocabulary and the lack of preparation in oral communication. It is difficult for them to engage in oral communication activities in English. These findings are in line with what has been said by Syakuro (2014) and Rabani (2013) which states that the causes of obstacles in communicating verbally may arise due to psychological and media factors. Mature preparation and self-confidence are examples of psychological factors. While the vocabulary and topic discussed is including media factor in oral communication.

As for things that require improvement, students generally feel that the confidence and the amount of vocabulary that is mastered should be improved in order to improve the quality of oral communicating in English. This is reasonable because it should be that oral communication is the ability to speak the sounds of language to express or convey thoughts, ideas or feelings orally (Brown and Yule, 1983).

\section{E. CONCLUSIONS AND SUGGESTIONS}

\section{Conclusions}

Based on the data analysis of the research results, it can be interpreted in general outline response of students of English literature to oral communication in English is as follows:

\section{A. Oral Communication}

a. In general, formal oral communication is considered very important to be mastered,

b. Feel capable of inactivating oral communication in informal form.

B. Linguistic and non-linguistic factors

a. the choice of words and the composition of sentences that are good and true felt very important in engaging in English oral communication activities;

b. talking with confidence, pronunciation with proper English pronunciation and mastering the topic of conversation into non-linguistic factors that are considered very important;

c. loudness and facial mimic while engaging in oral communication activity in English. In general, students feel it is not important enough to master.

C. Situation

a. Mature preparation, self-confidence, and mastery of vocabulary and things discussed become factors that facilitate the activity of oral communication;

b. Difficult vocabulary and lack of preparation in oral communication is difficult for them to engage in oral communication, communication in English; 
c. In general, students feel that the confidence and number of vocabularies that are mastered should be improved in order to improve the quality of oral communicating in English.

\section{Suggestions}

Suggestions that can be submitted as a material of further thinking are as follows:

1. To be able to maximize again in terms of the number of students and the coverage area involved in the research, so that the findings of research can be more representative and reliable.

2. It is expected that the findings on the need for oral communication in English can be developed as a basis for the development of syllabus in the teaching of English so that the learning of English can be adapted to the needs of the students.

\section{F. REFERENCES}

Allwright, R. (1979). Language Learning Through Communication Practice. In Brumfit, C., and Johnson, K. (eds.) The Communicative Approach to Language Teaching. Oxford: Oxford University Press.

Arista, A.C. (2011).Review JurusanSastraInggris.[Online]. Available at:www.jurusankuliah.net

Bada, E. \& Okan, Z. (2000). Student's Language Learning Preferences. TESL Journal Vol. 4 No.3. [Online].

Available at: http://www.writing.berkeley.edu/TESL-EJ/ej15/a1.html

Brown, G. and Yule, G.(1983).Discourse analysis. Cambridge: Cambridge University. Press,.

Burns, R. (2000). Introduction to Research Methods: Fourth Edition. San Fransisco: Addison Wesley Longman, Inc.

Djago,et al. (1997).Pengembangan Keterampilan Berbicara. Jakarta: PTK.

Fathiroh, A. (2012). Define: SastraInggris.[Online]. Available at:www.jurusankuliah.tumblr.com

Harmer, J. (2001). The Practice of English Language Teaching. Edinburgh: Pearson Education.

Harmer, J. (2002). The Practice of English Language Teaching. $3^{\text {rd }}$ ed. Longman.

Harmer, J. (2007). How to Teach English. Longman. England.

Hartaji, D. A. (2012). Motivasi Berprestasi Pada Mahasiswa yang Berkuliah Dengan Jurusan Pilihan Orangtua. Fakultas Psikologi Universitas Gunadarma. (tidakditerbitkan)

Heriyaningsih. (2010). Macam-macamkomunikasi.[Online]. Available at:www.hery_yaningsih.blogspot.co.id

Hutchinson, T., and Waters, A.( 1987). English for Specific Purposes: A Learner Centered Approach. Cambridge University Press.

KamusBesarBahasa Indonesia Online.[Online]. Available at: www.kbbi.web.id

Madsen,H.(1983).Language Arts \& Disciplines. OUP USA.

New Strait Times. (2007). https://www.highbeam.com/publications/new-straits-times-p434962

Nunan, D. (1988). The Learner-Centred Curriculum. Britain: Cambridge University Press.

Nunan, D. (2001). Syllabus Design. Oxford: Oxford University Press.

Rabani, A. (2013). Pengertiankomunikasi, Unsurkomunikasi, hambatankomunikasi,

klasifikasidalamorganisasi.[Online]. Available at:www.adenrabani.wordpress

Richards, J.C. (2001). Curriculum Development in Language Teaching. UK: Cambridge University Press.

Siswoyo, D. (2007).Ilmu Pendidikan. Yogyakarta: UNY Pers.

Stevens, B. (2005). Communication Skills What Do Employers Want? Silicon Valley.Responding recruiters. Journal of Employment Counseling,. 42 (1): 2. [Online]. Available at:http://proquest.umi.com/ [August 1, 2007]

Syakuro, A. (2014). FaktorPenunjangdanpenghambatkegiatanberbicara.[Online]. Available at:www.mediapidato.com Tarigan, H.G. (1981). Berbicara sebagai suatu keterampilan berbahasa. Bandung: Angkasa. Yusuf, S.(2000). Psikologi PerkembanganAnak Dan Remaja. Bandung: PT Remaja Rosdakarya. 